Business Cycles, Economic Anaysis of data for Brazil Crises, and the Poor

suggests that poverty

responds asymmetrically to output shocks, showing less

Testing for Asymmetric Effects tendency to fall in response to a positive shock when the economy is initially in a

Pierre-Richard Agénor downturn

The World Bank

World Bank Institute

Economic Policy and Poverty Reduction Division

October 2001 
Policy Research Working Paper 2700

\section{Summary findings}

Agénor examines whether output contractions associated with cyclical output fluctuations and economic crises have an asymmetric effect on poverty. He identifies four potential sources of asymmetry: expectations and confidence factors, credit rationing at the firm level (induced by either adverse selection problems or negative shocks to net worth), borrowing constraints at the household level, and the "labor hoarding" hypothesis. He also identifies some testable implications of these alternative explanations.
The author then proposes a vector autoregression technique (involving the detrended components of real output, the unemployment rate, real wages, and the poverty rate) to test whether the initial cyclical position of the economy, and the size of the initial drop in the output gap in a downturn, matter in assessing the extent to which output shocks affect poverty. He applies the technique to Brazil, using annual data for 1981-99. The results indicate that poverty responds asymmetrically to output shocks, showing less sensitivity when the economy is initially in a downturn.

This paper-a product of the Economic Policy and Poverty Reduction Division, World Bank Institute-is part of a larger effort in the institute to analyze the impact of macroeconomic adjustment on poverty. Copies of the paper are available free from the World Bank, 1818 H Street NW, Washington, DC 20433. Please contact Maria Gosiengfiao, room J4-282, telephone 202-473-3363, fax 202-676-9810, email address mgosiengfiao@worldbank.org. Policy Research Working Papers are also posted on the Web at http://econ.worldbank.org. The author may be contacted at pagenor @ worldbank.org. October 2001. (29 pages)

The Policy Research Working Paper Series disseminates the findings of work in progress to encourage the exchange of ideas about development issues. An objective of the series is to get the findings out quickly, even if the presentations are less than fully polished. The papers carry the names of the authors and should be cited accordingly. The findings, interpretations, and conclusions expressed in this paper are entirely those of the authors. They do not necessarily represent the view of the World Bank, its Executive Directors, or the countries they represent. 


\title{
Business Cycles, Economic Crises, and the Poor: Testing for Asymmetric Effects
}

\author{
Pierre-Richard Agénor \\ The World Bank \\ Washington DC 20433
}

*I would like to thank, without implication, Fernando Blumenschein and Francisco Ferreira for very helpful discussions and advice on the data for Brazil used in the paper, Joshua Aizenman, Alejandro Izquierdo, and Roberto Steiner for comments on a previous draft, and Nihal Bayraktar for excellent research assistance. 



\section{Table of Contents}

I. Introduction

II. Sources of Asymmetric Effects: Theory

1. Expectations and Confidence Factors

2. Adverse Selection, Net worth, and Credit Rationing

3. Borrowing Constraints and Household Consumption

4. The "Labor Hoarding" Hypothesis

III. Testing for Asymmetric Effects: Methodology

IV. An Application to Brazil, 1981-99

IV. Concluding Remarks

Appendix A: Brazil--Data Sources and Unit Root Tests

References

Figures 



\section{Introduction}

The empirical evidence on the social costs of the East Asian financial crisis has provided a vivid illustration of the devastating impact that large output contractions can have on the poor. In Indonesia, for instance, the incidence of poverty (measured on the basis of the national poverty line) rose from $11 \%$ to $18 \%$ between 1996 and 1999. In Korea, the urban poverty headcount index rose from $8.5 \%$ to $18 \%$ in $1997-98$; and in Thailand, the incidence of poverty increased from $11.4 \%$ in 1996 to $12.9 \%$ in 1998 (Krongkaew (2000)). Income of the poor fell as a result of both lower wages and higher unemployment (Horton and Mazumdar (2001)). During the period 1997-98, real wages fell by $4.5 \%$ in Thailand, $10.6 \%$ in Korea, and $44 \%$ in Indonesia (World Bank (2000)). In Thailand the open unemployment rate rose from $2.2 \%$ in 1997 to $5.3 \%$ in 1998 , whereas in Korea the urban unemployment rate rose from $2.6 \%$ in 1997 to $8.4 \%$ in early 1999. In Indonesia, the increase in open unemployment was less dramatic but was accompanied by a significant shift toward the informal sector and a rise in "disguised" unemployment. ${ }^{1}$

Various arguments have been offered to explain why economic crises may hurt the poor most. One argument is that the poor often lack the means to protect themselves from adverse income and employment shocks. They lack assets (such as bank deposits and land) and often have no direct access to credit markets (or face prohibitive borrowing costs when they do), to smooth the impact of these shocks. For the very poor, unfavorable shocks may be large enough to actually result in declines in consumption, bringing it down below subsistence leveis and affecting their long-term nutrition and health prospects. A second argument is that due to the lack of education and skills, the poor tend to be less mobile (across sectors and regions) than better-educated workers and

${ }^{1}$ The effect of the crisis on very poor households In Indonesia was also exacerbated by the dramatic increase in their cost-of-living index, which resulted to a large extent from the impact of the sharp depreciation of the exchange rate on domestic prices (see Levinsohn, Berry, and Friedman (2001)). 
are therefore often unable to switch jobs and capitalize on available employment opportunities (see for instance Neri and Thomas (2000) for Brazil). A third argument is that indirect sources of income and public transfers may cecline during crises, because during such episodes the ability of relatives (or communities) to engage in income redistribution may be reduced and governments may be forced to adjust drastically their fiscal accounts with acrossthe-board cuts in expenditure.

More recently, it has also been argued that cyclical downturns and economic crises may have an asymmetric effect on poverty. Recessions and/or sharp output contractions tend to increase poverty rates significantly (through some of the channels identified above), whereas expansions tend to have a more limited effect. Lustig (2000), for instance, argued that the fall in real income associated with economic downturns may have an irreversible impact on the human capital of the poor. Her argument is that children in poor families (particularly the very poor ones) are sometimes taken out of school and put to work in response to large adverse shocks-thereby mitigating the fall in the household's income-but do not return to school when the "good times" roll again. To the extent that adverse shocks to household income affect adversely investment in schooling (in addition to nutrition and health) and the longer-run ability of the poor to enhance their stock of human capital, they will hinder their ability to escape from poverty. Thus, large recessions create some sort of "asymmetric hysteresis" effect on poverty, in the sense of temporary negative shocks having persistent effects. ${ }^{2}$ However, the evidence supporting this view is mixed; for instance, Neri and Thomas (2000) found that in Brazil, children are not more likely to drop out of school in recessions than during expansions.

\footnotetext{
${ }^{2}$ There have been few attempts to test rigorously whether transitory shocks to poverty (induced or not by changes in output) may affect the trend (or permanent component) of poverty, as the "hysteresis" argument would imply. Lokshin and Ravallion (2000) used dynamic panel data in a study of household incomes in Hungary to assess the persistence of shocks. A time-series based approach could dwell on the unobserved components technique used by Jaeger and Parkinson (1990) to test for hysteresis in unemployment.
} 
Understanding the sources of asymmetric effects of economic cycles and crises on poverty, and assessing the strength of these effects, have critical policy implications, particularly for the design of social safety nets. It is also important for evaluating the welfare costs of crises and for judging the correlation between growth and poverty. Several recent studies have argued that this correlation is significantly negative. After reviewing a variety of empirical studies, Lustig (2000) for instance concluded that, in Latin America, for every percentage point decline in output growth, poverty rises by approximately two percent. Others estimate that in Brazil, in particular, the number of poor decreases by approximately 0.6 percent for every percentage point increase in GDP (Neri and Thomas (2000)). However, in the presence of asymmetry, this relationship is misleading. As noted by De Janvry and Sadoulet $(2000$, p. 284), if it results essentially from associations that pertain to recessions rather than expansions, it may lead to erroneous predictions about the potential of growth-oriented policies to reduce poverty. In fact, the regression results produced by De Janvry and Sadoulet (2000) show that the effect of income changes on poverty tends indeed to be asymmetric; a one percent decline in the growth rate of income can annihilate the poverty-reduction effects of more than one percent of income growth.

Nevertheless, formal empirical evidence on the asymmetric effects of changes in output on poverty remains very scant. This paper attempts to contribute to the debate by examining whether output shocks associated with either cyclical fluctuations or economic crises (which are often characterized by a sharp contraction in real activity) have an asymmetric effect on poverty. Specifically, it addresses two related issues. The first is whether the initial cyclical position of the economy (that is, whether the economy is in a recession as opposed to an expansion phase) matters in assessing whether output shocks have an asymmetric impact on the poor. The second is whether the magnitude of the initial drop in the level of output below trend in a downturn ("normal" recessions associated with the business cycle as opposed to the "large" output contractions observed during periods of economic crisis) may generate asymmetries in the response of poverty to output shocks. 
The remainder of the paper is organized as follows. Section II identifies four alternative channels through which output shocks can have nonlinear effects on poverty-in the sense of generating not only asymmetric responses but also regime switches and jumps between equilibria. These channels are expectations and confidence factors; credit rationing at the level of firms; bor owing constraints at the household level; and the "labor hoarding" hypothesis. Section III proposes a simple vector autoregression technique (involving the detrended components of real output, real wages, the unemployment rate, and the foverty rate) to test for the existence of the two types of asymmetric effects described earlier. This technique is then applied in Section IV to Brazil, using annual data covering the period 1981-99. Finally, Section $V$ summarizes the main results of the analysis, draws some policy implications, and identifies possible directions for future research.

\section{Sources of Asymmetric Effects: Theory}

This section discusses several channels through which, and conditions under which, movements in output (associated, again, with either "normal" cyclical movements or full-blown crises) can have an asymmetric effect on poverty. Four main classes of explanations are distinguished. The first is based on asymmetric changes in expectations and confidence factors; the second on a "credit crunch" at the firm level, with rationing induced by either adverse selection problems or negative shocks to net worth; the third emphasizes the impact of borrowing constraints on household consumption behavior; and the fourth dwells on "labor hoarding" by firms facing high turnover costs. Whereas credit and borrowing constraints are, in a sense, "induced" by the initial adverse stock to output, the labor hoarding hypothesis can be viewed as capturing a "pure" asymmetric effect. 


\section{Expectations and Confidence Factors}

The first possible source of asymmetry in the impact of output shocks on poverty relates to expectations and confidence factors. The argument is that confidence in the economy's prospects may change over the course of the business cycle and during crises. In particular, consumers and firms may be more pessimistic during recessions and crises than they are optimistic during expansions, or immediate prospects may matter more during recessions than future prospects. If consumers and firms worry more about the overall economic outlook and the economy's likely direction in a downturn, a positive output shock-induced by, say, a fiscal expansion--may have a smaller impact (and thus be less effective) on private spending decisions during recessions than during booms. In addition, if the degree of uncertainty about future profitability rises during recessions at the same time that concerns about future profitability increase, firms may be less willing to invest--even after a large (policy-induced) positive shock to aggregate demand. The reason, of course, is the "option value" associated with waiting for the uncertainty to dissipate (Dixit and Pindyck (1994)). If output and labor demand become less sensitive to positive shocks when the output gap is initially negative, the initial increase in poverty induced by higher unemployment may be difficult to reverse.

\section{Adverse Selection, Net Worth, and the "Credit Crunch" View}

Recessions and economic crises may be accompanied by high or increasing interest rates for at least two reasons. First, an economic slowdown may raise the risk of default (by increasing the incidence of adverse shocks on profitability, for instance). This may lead banks to raise the premium that they charge over and above the cost of funds, as for instance in the model of Agénor and Aizenman (1998), despite downward pressure on interest rates resulting 
from a reduction in the demand for credit. Second, at least during the initial phases of economic crises (more than during "normal" recessions), the need to defend the domestic currency on foreign exchange markets and fend off speculative attacks often forces the central bank to raise interest rates. In practice, of course, both factors may be at play and may exacerbate the adverse impact of high borrowing costs on output--particularly if, as is often the case in developing countries, firms rely significantly on bank lending to finance their short-term working capital needs (Agénor and Aizenman (1998)).

Moreover, an initial increase in interest rates can lead to a tightening of credit constraints if banks are unwilling to lend to riskier borrowers, as implied by adverse selection models of the credit market of the Stiglitz-Weiss variety (see, for instance, Jaffee and Stiglitz (1990)). A rise in policy interest rates, for instance, may lead to higher market interest rates and higher deposit rates. Banks, however, may be reluctant to pass on to borrowers, in the form of higher loan rates, the higher cost of funds that they face. The reason is that because higher loan rates increase the debt burden of borrowers and may raise the risk of default (as noted earlier), only riskier borrowers are willing to take on loans. To avoid the deterioration in the quality of their loan portfolio, banks may opt to ration credit. The tightening of credit constraints magnifies the impact of the initial recession or output contraction on borrowing and spending, through a direct supply-side effect. The resulting fall in labor demand and thus the effect on poverty may also be (all else equal) compounded. Thus, if credit constraints bind only in periods in which output is below capacity, they may impart an asymmetric bias to output shocks. ${ }^{3}$

\footnotetext{
${ }^{3}$ Note that quantity rationing is sufficient but not strictly necessary to explain asymmetry. The same information problems that lead to quantity rationing may lead banks to charge a steep risk premium over the (risk-free) market interest rate for a given loan size. Even if fi-ms can borrow at that rate, they may still be "credit constrained" because the premium may lead them to forego profitable projects that cannot be financed internally.
} 
Two factors may compound the incidence of a credit crunch induced by information problems:

- The first is related to the fact that recessions, and more significantly economic crises, are sometimes accompanied by a process of concentration in the financial system, with smaller financial institutions being forced to close or undergo thorough restructuring of their operations. This often translates into a loss of information about potential bank borrowers. If, as a result, adverse selection problems are exacerbated, the credit crunch may become highly persistent.

- The second factor is related to the observation that, in many developing countries, small and medium-size firms (particularly in the manufacturing sector) tend to be more dependent on bank credit than large firms. They may therefore suffer the most from a credit crunch induced by a perceived increase in the risk of default in a downturn. And because small and medium-size enterprises tend to use more labor-intensive production technologies, the reduction in output and employment induced by the drop in the availability of credit may be particularly large, implying a potentially severe adverse effect on poverty. Some recent evidence on the East Asia crisis suggests indeed that the sharp increases in interest rates that were implemented to defend the exchange rate during the crisis had large distributional and poverty effects (see Domac (1999)).

An alternative argument that may explain a credit crunch in an economic downturn is based on net worth effects. In a crisis, the collapse in asset prices (e.g. real estate or equity prices) may lead to a sharp drop in the value of the collateral against which firms borrow. To the extent that firms (particularly small and medium-size ones) have limited alternatives to secure loans, banks may curtail credit because of the drop in value of assets that they can seize in case of default, possibly affecting smaller firms the most. A lower level of credit will, again, reduce output and employment, and eventually increase the incidence of poverty. An asymmetric effect may result from the fact that, after the crisis, 
economic uncertainty may remain high, expectations may remain pessirnistic, entailing as a result a slow recovery of asset prices.

It is worth noting also that the sharp exchange rate depreciation that often accompanies financial crises (as was the case in East Asia, for instance) may also reduce dramatically the net worth of domestic bank borrowers, big and small, if their level of unhedged foreign-currency debt is high. Again, this may lead banks to curtail collateralized credit. Asymmetric effects may resul: from persistent uncertainty regarding the exact size of borrowers' foreign liabilities, and thus how healthy their balance sheets are, even when the dornestic economy starts to recover. Thus, the balance sheet conditions of firms can amplify fluctuations in output and negative shocks are likely to have a greater effect than positive shocks. The fundamental reason is that net worth effects make access to the credit market pro-cyclical. ${ }^{4}$

\section{Borrowing Constraints and Household Consumption}

A third potential source of asymmetry in the response of poverty to output shocks relates to credit constraints and their impact on the ability of households to smooth consumption. The reason is that, as discussed earlier, such constraints may become binding during recessions, as a result of adverse selection or net worth effects, because household wealth may be also adversely affected by sharp drops in asset prices. In addition, increases in interes: rates may cause an asymmetric effect on consumption (and thus poverty) through permanent income effects. In the model of Jackman and Sutton (1982), for instance, higher interest rates may force constrained consumers to reduce spending by the full amount that their loan payments increase. Lower rates relax

\footnotetext{
${ }^{4}$ For instance, in the models of Bernanke and Gertler (1989) and Bernanke, Gertler, and Gilchrist (1999)), firms may be credit constrained because of low collateral. When firms are fully collateralized, and hence unconstrained, sharp declines in investment spending are more likely than sharp increases. The reason is that credit constraints typically bind during recessions, when net worth is low.
} 
the constraint, but spending increases less than proportionately because consumers spread out their spending across time.

In principle, the possibility of binding borrowing constraints in adverse state of nature does not, by itself, result in an asymmetric effect. The reason is that households may well be able to achieve some level of consumption smoothing by depleting their assets (selling land, for instance) or using nonmarket mechanisms (such as increased own production). It is also possible that households may "internalize" state-dependent credit constraints. In particular, they may decide, in response to income risk, to accumulate more assets or engage in precautionary savings in "good" times in order to shelter consumption in "bad" times; recent evidence on this type of ex ante risk-mitigating strategy is provided by Agénor and Aizenman (2000) for sub-Saharan Africa.

Nevertheless, for the poor specifically, the available evidence suggests indeed that risk-sharing and consumption smoothing remain imperfect-if not unfeasible (see Morduch (1995, p. 107)). The poorest households are typically those least insured against shocks because of their inability to accumulate assets and because, as noted earlier, asymmetric information problems and high transaction costs may completely preclude access for them to private market insurance or credit mechanisms to smooth income fluctuations. As a result, consumption smoothing through borrowing and lending is simply not feasible. Poor households may then have no option but to engage in either sub-optimal labor allocation decisions (such as forcing children to quit school and work, as noted in the introduction), or to let consumption fluctuate as much as income-with possibly devastating long-run effects on health and nutrition.

\section{The "Labor Hoarding" Hypothesis}

Yet another source of asymmetry in the effect of output shocks on poverty is the "labor hoarding" hypothesis, highlighted in Agénor (1998). The argument is 
that recessions and crises worsen poverty because of an asymmetric effect on employment and productivity. In a recession or crisis-induced contraction, unskilled workers (among which the poor tend to be concentrated) are often the first to lose their jobs as firms "hoard" their trained labor force (skilled workers). The incentive to hoard is related to the existence of high turnover costs (hiring, training and firing costs) associated with the use of skilled labor, and is higher the more the shock is perceived to be temporary, regardless of its size. When the "good times" come back, firms may naturally want, in priority, to recoup the productivity losses and foregone profit opportunities incurred during the downturn and return their skilled labor force to a state of high productivity. Given the greater degree of complementarity between skilled labor and physical capital (that is, the fact that the elasticity of substitution between these two factors is generally lower than the elasticity of substitution between any of them and unskilled labor), they may be tempted to increase fixed investment instead of increasing their demand for unskilled labor. This may occur despite the fact that actual wages for that category of workers may fall proportionately more than skilled workers' wage and the price of capital, and unskilled workers' reservation wage may have been adjusted downward. Moreover, the tendency to hire skilled workers when the "good times" return may be particularly high if firms incurred sunk costs associated with investment in physical capital prior to the contraction in output. Thus, the combination of high turnover costs and a low degree of substitutability between skilled labor and physical capital may produce a strong degree of persistence in unskilled unemployment and poverty in the aftermath of a negative shock to output. 


\section{Testing for Asymmetric Effects: Methodology}

The various channels through which output shocks can generate asymmetric effects have different testing implications, which in principle could be used to discriminate among them in a particular sample. For instance, an empirical test of the "credit crunch" view would imply looking at the share of collateralized credit, the amount of firms' borrowing on world capital markets (or, more specifically, the share of unhedged, short-term foreign currency liabilities incurred by firms), the behavior of asset prices (including exchange rates) during periods of economic downturns, and more generally changes in balance sheets. Examining data on the composition of credit, namely, the share of lending going to small and medium-size firms, would also be important. The relevance of the "labor hoarding" hypothesis can be assessed by examining the importance of turnover costs, changes in the composition of the labor force and the behavior of productivity during recessions and upturns, and the behavior of physical investment immediately after crises. Indeed, as noted earlier, the hypothesis predicts a change in the composition of the factor mix (notably, an increase in capital and skilled labor intensity relative to unskilled labor) in the immediate aftermath of a recession or a large output contraction. Interestingly enough, Neri and Thomas (2000) found (using survey data for the past two decades) that in Brazil less-educated workers fell into poverty at a greater rate during recessions - a result consistent with the labor hoarding hypothesis.

The objective of this paper is, however, far less ambitious. As noted in the introduction, it focuses on two aspects of the debate: whether the initial cyclical position of the economy, and the magnitude of the initial drop in the level of output below trend in a downturn, matter in assessing the extent to which output shocks have an asymmetric effect on poverty. To this end, and given the focus of the present study on short-run dynamics, it proposes a standard vector autoregression (VAR) model involving a small set of stationary variables. 
Specifically, the variables that I suggest to include in the VAR are the detrended components of output, the open unemployment rate, real wages, and the poverty rate. ${ }^{5}$ These variables are chosen on the premise that adjustment to an output shock takes place in the short term primarily through two channels: either a change in unemployment or a change in real wages ${ }^{6}$ Controlling for changes in these two variables in assessing the impact of output shocks on poverty is thus essential. In general, of course, the impact of the shosk on poverty will depend on what group is hit the most by the rise in unemployment or the fall in real wages. If movements in these two variables affect primarily prime age working males with low education, poverty may increase significantly. Thus, it may be important to include in the VAR, in addition to standard measures of the cyclical component of output and the detrended component of (the log of) the poverty rate, a measure of unemployment that reflects well labor market conditions faced by unskilled workers (as a proxy for "vulnerable" groups), and a real wage index that is representative of wages earned by the poor-say, an index of unskilled workers' wage, or informal sector wages. It is also possible that changes in open unemployment are not highly correlated with output fluctuations, because adjustment to changes in labor demand takes the form of large movements in the labor force between the formal and informal sectors; in such conditions, the open unemployment rate should be replaced by a measure that captures such movements.

\footnotetext{
${ }^{5}$ Because these variables are likely to be stationary, using a vector cointegration approach is not required. An alternative approach would be to specify a VAR model in which all variables are measured in levels despite being nonstationary. As shown by Sims, Stock and Watson (1990), least-squares estimates are consistent for the levels specification (whether cointegration exists or not), whereas a differenced specification is inconsistent if some variables are cointegrated. But in the absence of cointegration, the estimated standard errors of the levels specification are not consistent, so conventional inference could potentially be misleading. Note also that testing for cointegration in the present case would be problematic, given the small size of the sample.

${ }^{6}$ However, as noted in the introduction, recessions and crises may be accompanied also by changes in intra-family allocation of income or government transfers. These changes can be expected to matter more during severe output contractions relative to "normal" cyclical downturns. The extent to which these variables matter, nevertheless, is case specific and can be formally tested using the block exogeneity test described below.
} 
Innovations in the output gap are used to measure real shocks, and the standard Choleski decomposition is used to identify impulse response functions. Specifically, to implement the Choleski decomposition of the covariance matrix, the disturbances in the model are assumed to follow the following causal ordering: output gap innovations--real wages innovations--unemployment rate innovations--poverty rate innovations. The fact that the output gap and the unemployment rate are placed before the poverty rate in the VAR captures the assumption that shocks to poverty have no contemporaneous impact on these variables. Any contemporaneous correlation between a disturbance to the poverty rate and the output gap, for instance, is thus taken to reflect causation from output to poverty, and not the other way around.

Once a VAR is specified, the second aspect of the procedure proposed here consists in specifying the way in which potential asymmetric effects of the business cycle and crises on poverty can be assessed. ${ }^{7}$ To test whether the effect of output shocks on poverty may depend on the initial phase of the business cycle, I use the sign of the output gap (positive or negative); and to test whether the size of initial adverse shocks matters, I use a distinction between "normal" recessions and "deep" contractions. The first test is implemented by partitioning the sample on the basis of whether (the logarithm of) the output gap is initially positive or negative. Specifically, let $D$ be a dummy variable that takes the value 1 if the output gap is positive and 0 otherwise, and let $x$ denote the output gap. To account for asymmetric effects the VAR system is expanded to five variables by replacing $x$ in the "symmetric" VAR model by two measures of the state of the business cycle: $x^{+}=D x$, and $x^{-}=(1-D) x^{8}$ To implement the second test, the sample is partitioned into three groups of observations: those for

\footnotetext{
${ }^{7}$ This follows Macklem (1995) and Agénor (2001).

${ }^{8}$ The ordering chosen has now $x^{+}$and $x^{-}$as the two most endogenous variables. The ordering of the latter two variables is purely arbitrary; but the results are not sensitive to the ordering shown here. In addition, I also entered the dummy variable directly in each of the equations of the expanded VAR so as to allow the intercept to shift along with the slope coefficients. The variable was not significant and was dropped from the final specification to economize on degrees of freedom. Finally, the optimal lag length chosen for the symmetric VAR is imposed in each case, in order to facilitate comparisons with the symmetric case.
} 
which the output gap is positive, those in which the output gap is negative but less than 4 percent in absolute terms, and those in which the output glap is negative and greater than 4 percent in absolute terms. The VAR is now expanded to six variables by replacing $x$ in the "symmetric" model by three measures of movements in output: $x^{+}=D x, x^{-S}=(1-D) Z x$, and $x^{-L}=(1-D)(1-Z) x$, where $Z$ is a dummy variable that takes the value 1 (respectively 0 ) if the drop in the output gap is smaller (respectively greater) than 4 percent. The idea rere is that negative shocks that entail a drop in output that is smaller than 4 percentage points represent "normal" recessions, whereas drops in the output gap that exceed 4 percentage points are associated with a "crisis" of some sort. Alt'ough the choice of a 4 percent threshold may appear to be somewhat arbitrary, there :s evidence to support this choice. Lustig (2000), for instance, in a study focusing on 23 countries in Latin America and the Caribbean during 1980 and 1998, Fund that there were over 40 episodes where GDP per capita fell by 4 percentage points or more. In another study, dwelling on a sample of 36 banking crises in 35 countries, Demirguc-Kunt et al. (2000) found that a banking crisis is typically accompanied by a decline in output growth of the order of 4 percentage points. Nevertheless, some sensitivity analysis would generally be warranted (see the discussion below)

To assess whether any of the two "control" variables (that is, either the unemployment rate or the real wage) or any additional variable (such as government transfers to the poor) should be included in the VAR, a block exogereity (or block causality) test can be performed by estimating both the "unrestricted" and "restricted" VARs (that is, with and without the cyclical component of the variable of interest) to obtain the variance-covariance matrix of the residuals associated with the unrestricted and restricted models, $\Omega_{U}$ and $\Omega_{C}$. Define the likelihood ratio statistic, $\lambda$, as

$$
\lambda=(T-c)\left(\log \left|\Omega_{c}\right|-\log \left|\Omega_{u}\right|\right)
$$


where $\left|\Omega_{C}\right|$ (respectively $\left|\Omega_{U}\right|$ ) is the determinant of $\Omega_{C}$ (respectively $\Omega_{U}$ ), $T$ the number of observations, and $c$ the number of parameters (equal to the number of lags times the number of variables, plus one for the constant term) estimated in each equation of the unrestricted system. This statistic has a $\chi^{2}$ distribution with degrees of freedom equal to the number of restrictions in the system, equal to one times the number of lags.

\section{An Application to Brazil, 1981-99}

The above procedure was applied to Brazil, using annual data over the period 1981-99. Brazil is an interesting case to test the methodology described in the previous section because of the availability of sufficiently long time-series data to ensure adequate degrees of freedom. It is also one of the few countries for which several ongoing studies have focused on assessing the impact of macroeconomic variables on poverty. Paes de Barros et al. (2000), for instance, in a study based on micro-simulation techniques, found that unemployment has a major impact in relative terms on the behavior of poverty rates. ${ }^{9}$

The variables included in the VAR, in addition to the (log of the) output gap, are the cyclical components of the (log of the) aggregate unemployment rate, the real minimum wage (which plays a key role in the distribution of wages in Brazil, as noted for instance by Neri and Thomas (2000)), and the poverty headcount index. Capacity output (with output measured by real GDP) is measured using a univariate technique, the Hodrick-Prescott (HP) filter (see Hodrick and Prescott (1997)). ${ }^{10}$ More precise definitions of these variables are

\footnotetext{
${ }^{9}$ Neri and Thomas (2000) analyzed the effects of aggregate shocks on the poor in Brazil, using incomes rather than consumption expenditures. See De Ferranti et al. (2000, pp. 76-77) for a discussion of their results.

${ }^{10}$ It should be kept in mind, however, that because of the difficulties involved in measuring capacity output, the output gap is likely to be subject to a significant margin of error.
} 
provided in the Appendix, which also reports the results of standard Augmented Dickey-Fuller stationary tests. These results indicate that all the variables, as defined here, are stationary. A "standard" VAR approach (that is, one that ignores cointegrating relationships between the variables in level form) can therefore be used. The real minimum wage is used as a proxy for the unskilled real wage; evidence for Brazil indicates that these two series are indeed highly correlated. Nevertheless, to verify that the real minimum wage "belongs" to the VAR, I applied the block exogeneity test described earlier. As reported in the Appendix, the results indicate that the null hypothesis (exclusion of the cyclical component of the real minimum wage from the VAR) is soundly rejected by the likelihood ratio test.

Figure 1 shows the evolution of the cyclical components of al the variables included in the VAR. The data illustrate fairly well the pro-cyzlical behavior of the real minimum wage and the counter-cyclical behavior of the unemployment and poverty rates. ${ }^{11}$ Given my 4 percent threshold, the data indicate that 1983,1984 , and 1992 can be identified as "crisis" periods.

The impulse response functions over 24 years associated with a one standard deviation shock to the innovation in the output gap are shown in Figures 2, 3 and 4, for both the symmetric and asymmetric cases. The solid lines in the figures represent the impulse responses themselves, whereas the dotted lines are the associated 95 percent upper and lower confidence bands. ${ }^{12}$ Given the relatively small size of the sample, the use of standard criteria for choosing the optimal lag length (such as the Akaike criterion) is not feasible; instead, I relied on a visual inspection of the impulse response functions associated with an output shock in the symmetric case and compared the results with one and

\footnotetext{
${ }^{11}$ Note the sharp drop in the cyclical component of the poverty and unemployment rates in 1986, which reflects movements in the original series. The data compiled by Wodon et al. 2001) indicate also, as in the dataset used here, a sharp drop in poverty in that same year.

12 The impulse responses and their associated confidence intervals are computed using Monte Carlo simulations employing 1,000 draws.
} 
two lags. The results are shown in Figure 2; they indicate clearly that the degree of significance is very similar in both cases, although the impulse responses are (as can be expected) a bit more "choppy" with two lags compared with one lag. Accordingly, and to economize degree of freedom, I examine the asymmetric cases using the one-lag VAR.

The results of the first experiment are reported in Figure 3. They show a clear asymmetric response in the real minimum wage and the unemployment rate, depending on the size of the initial output gap: when output is initially above trend, a positive output shock raises real wages and lowers unemployment (as theory would suggests), in addition to reducing poverty. All three effects are statistically significant, but the wage and poverty effects dissipate fairly rapidly. By contrast, when output is initially below trend (whether it is a "normal" recession or a "crisis-related" contraction, according to the definition adopted above) only the poverty effect is significant--and barely so.

Figure 4 reports the second experiment. The results obtained when the output gap is positive are very similar in size and degree of significance to those reported in the previous figure. However, now neither the poverty effect nor the unemployment effect are significant when the output gap is initially negative, regardless of whether the fall in output exceeds 4 percent. There is a delayed, significant response of the real minimum wage that lasts for about a year, in the direction expected.

To assess (at least to some degree) the robustness of the results, I performed two types of sensitivity tests. First, I considered several alternative orderings, with the poverty rate always appearing last in the sequence; the results remained virtually unchanged. Second, the asymmetric experiments were repeated with a 3 percent threshold for the drop in the output gap. The results, again, were virtually identical to those reported here. The conclusion, then, is that the response of the poverty rate to output shocks is state dependent; when output is initially above trend, any positive shock tends to lower poverty. By contrast, in a recession or in a period of severe contraction, output 
shocks have no discernible effect on poverty-and neither do they affect unemployment. These results are consistent with several aspects of the various sources of asymmetry described earlier. In particular, more pessinistic expectations about future profitability in a downturn may lead firms to refrain from expanding their labor force--even in response to a positive shock to aggregate demand.

\section{Concluding Remarks}

Recent research on the impact of economic crises on the pocr has emphasized that temporary negative income shocks may have permanent effects on poverty. In addition to this "hysteresis" effect, it has also been recognized that over the short run business cycles and economic crises may have an asymmetric effect on poverty-poverty may increase more during periods of economic contractions than it decreases in an equivalent expansion. A common explanation is that parents may be forced to take their children out of school to engage them in income-generating activities (Lustig (2000)). Even though a recession typically lowers the opportunity cost of schooling, a rinding subsistence constraint may force poor households to reallocate their children's time away from schooling and toward work. Because of the irreversibilities that characterize investment in education, even short-lived crises may have serious long-term detrimental effects on the ability of the poor to escape poverty. However, the formal evidence in favor of this interpretation remains weak.

This paper attempted to contribute to the existing literature on asyn metric effects by focusing on two related issues. The first is whether the initial cyclical position of the economy (that is, whether the economy is in a recession as opposed to an expansion phase) matters in assessing whether output shocks have an asymmetric effect on poverty. The second is whether the magnitude of 
the initial drop in the level of output below trend in a downturn ("normal" recessions associated with the business cycle, as opposed to a "severe" contraction induced by an economic crisis) may generate asymmetries in the response of poverty to output shocks. The first part of the paper provided a review of several alternative channels through which output shocks can have nonlinear effects on poverty. They include expectations and confidence factors; credit rationing at the level of firms; borrowing constraints at the household level; and the "labor hoarding" hypothesis. The "credit crunch" argument is based on the view that higher interest rates (which may be implemented in the context of an economic crisis to defend the exchange rate) do not only have a negative demand and supply-side effects; they also tend to discourage less risky potential borrowers. If lenders have no adequate way of discriminating between high and low-risk borrowers and internalize this adverse selection problem, a marketclearing equilibrium may not exist, and instead there may be persistent credit rationing-particularly of small and medium-size enterprises, prepared to pay higher interest rates, but unable to obtain any funds. The second part proposed a simple vector autoregression technique (involving the detrended components of output, real wages, the unemployment rate, and the poverty rate) to test for the existence of the two types of asymmetric effects described earlier. The third part applied this technique to Brazil, using annual data for the period 1981-99. The results of impulse response analysis indicated that the response of the poverty rate to output shocks is state dependent; when output is initially above trend, any positive shock tends to lower poverty. By contrast, in a recession or in a period of severe contraction, output shocks have no discernible effect on poverty-and neither do they affect unemployment.

There are several directions in which the present study can be extended. The first is to broaden the sample to consider a time-series, cross-section dataset of "economic crises" and a comparative sample of "tranquil times," in order to assess (using possibly panel VARs) the extent to which the results reported here for Brazil hold more generally. Another direction is to abandon the "standard" VAR approach and use a vector error correction model that integrates 
both the short- and long-run effects of output shocks on poverty. This is, however, a more demanding task, because it requires a model that explicitly accounts for the long-term determinants of poverty, such as access to education and the degree of labor mobility across sectors. Finally, a more amb tious agenda would be to devise a test that would allow researchers to discriminate between the different sources of asymmetric effects highlighted earlier. This is important because mitigating the impact of different sources of asymmetry requires different types of policy responses. For instance, whereas it is difficult for policymakers to have much direct impact on expectations and conficence factors, they may have more leeway in influencing hiring and firing costs--and thus in mitigating their disincentive effects on the demand for unskilled labor in a sharp contraction. 


\section{Appendix \\ Brazil: Data Sources and Unit Root Tests}

This Appendix describes the sources of the data for Brazil used in this paper and unit root tests on the raw series. The data cover the period 1981-99 and are defined as follows:

Y_CYC: Cyclical component of real GDP calculated as the log difference of real GDP and its trend component, calculated by using the Hodrick-Prescott filtering method. Data source for real GDP: World Development Indicators 2000, World Bank.

POVER_CYC: Cyclical component of the poverty headcount index, calculated as described in the definition of $Y$ CYC. There are two missing points in the poverty headcount index series, 1991 and 1994 . These missing points are substituted by the fitted values that are obtained by running an OLS regression with the log of the poverty headcount index as the dependent variable, and the $\log$ of the unemployment rate and the log of real GDP as independent variables. The data source for the index is the IPEA website (www.ipea.gov.br).

WAGE_CYC: Cyclical component of the real minimum wage, calculated as described in the definition of $Y_{-} C Y C$. The data source for this series is also the IPEA website (annual averages are calculated from the monthly data).

UNEMP_CYC: Cyclical component of the unemployment rate, calculated as described in the definition of $Y_{-} C Y C$. The data source for unemployment rate is also the IPEA website (obtained in turn from the monthly employment survey of IBGE, with annual averages are calculated from the monthly data).

POS (NEG): Dummy variable which is equal to one times $Y_{-}$CYC whenever $Y_{-} C Y C$ is positive (negative) and zero otherwise.

NEG_L: Dummy variable which is equal to one times $Y_{-}$CYC whenever $Y \_C Y C$ is less than $-4 \%$ and zero otherwise.

NEG_S: Dummy variable which is equal to one times $Y_{-}$CYC whenever $Y_{-} C Y C$ is between $-4 \%$ and 0 and zero otherwise. 
The block exogenity test statistic to check whether the cyclical component of the unemployment rate belongs to the VAR system that includes the output gap and the detrended component of the poverty rate is 73.0, with 2 degrees of freedom (statistically significant at 1 percent significance level). The same test statistic to check whether the cyclical component of the real minimum wage belongs to the VAR system that includes the output gap and the detrended components of unemployment and the poverty rates is 78.1 with 2 degrees of freedom (statistically significant at 1 percent significance level).

The unit root (Augmented Dickey Fuller) test statistic for the cyclical component of the poverty rate is -3.418 and significant at a 5 percent significance level according to Mackinnon's critical values for rejection of the null hypothesis of a unit root. The unit root test statistic for the detrended component of unemployment rate is -2.978 and significant at 10 percent. The unit root test statistic for the cyclical component of the real minimum wage -3.889 and significant at 1 percent. Finally, the unit root test statistic for the detrended component of real GDP is -4.975 and significant at 1 percent. 


\section{References}

Agénor, Pierre-Richard, "Stabilization Policies, Poverty and the Labor Market: Analytical Issues and Econometric Evidence," unpublished, the World Bank (December 1998).

----, "Asymmetric Effects of Monetary Policy Shocks," unpublished, the World Bank (August 2001).

Agénor, Pierre-Richard, and Joshua Aizenman, "Contagion and Volatility with Imperfect Credit Markets," IMF Staff Papers, 45 (June 1998), 207-35.

-.-.-, "Savings and the Terms of Trade under Borrowing Constraints," Working Paper No. 774, National Bureau of Economic Research (June 2000). Forthcoming, Journal of International Economics.

Bernanke, Ben S., and Mark Gertler, "Agency Costs, Net Worth and Business Fluctuations," American Economic Review, 79 (March 1989), 14-31

Bernanke, Ben S., Mark Gertler, and Simon Gilchrist, "The Financial Accelerator in a Quantitative Business Cycle Framework," in Handbook of Macroeconomics, ed. by John B. Taylor and Mark Woodford, North Holland (Amsterdam: 2000).

De Ferranti, David, Guillermo E. Perry, and Luis Servén, Securing our Future in a Global Economy, the World Bank (Washington DC: 2000).

De Janvry, Alain, and Elisabeth Sadoulet, "Growth, Poverty, and Inequality in Latin America: A Causal Analysis," Review of Income and Wealth, 46 (September 2000), 267-87.

Demirguc-Kunt, Asli, Enrica Detragiache, and Poonam Gupta, "Inside the Crisis: An Empirical Analysis of Banking Systems in Distress," Working Paper No. 00/156, International Monetary Fund (October 2000).

Domac, Ilker, "The Distributional Consequences of Monetary Policy: Evidence from Malaysia," PRE Working Paper No. 2170, the World Bank (August 1999).

Dixit, Avinash, and Robert S. Pindyck, Investment under Uncertainty, Princeton University Press (Princeton, New Jersey: 1994).

Hodrick, Robert J., and Edward C. Prescott, "Postwar U.S. Business Cycles: An Empirical Investigation," Journal of Money, Credit, and Banking, 29 (February 1997), 1-16. 
Horton, Susan, and Dipak Mazumdar, "Vulnerable Groups and the Labor Market: The Aftermath of the Asian Financial Crisis," in East Asian Labor Markets and the Economic Crisis, ed. By Gordon Betcherman and Rizwanul Islam, the World Bank (Washington DC: 2001).

Jackman, Richard, and John Sutton, "Imperfect Capital Markets and the Monetarist Black Box: Liquidity Constraints, Inflation and the Asymmetric Effects of Interest Rate Policy," Economic Journal, 92 (March 1982), 108-28

Jaeger, A., and M. Parkinson, "Testing for Hysteresis in Unemployrnent: An Unobserved Components Approach," Empirical Economics, 15 (June 1990), 185-98.

Jaffee, Dwight, and Joseph Stiglitz, "Credit Rationing," in Handbook of Monetary Economics, Vol. II, ed. by Benjamin M. Friedman and Frank H. Hahn, North Holland (Amsterdam: 1990).

Levinsohn, James, Steven Berry, and Jed Friedman, "Impacts of the Indonesian Economic Crisis: Price Changes and the Poor," unpublished, University of Michigan (February 2001).

Lokshin, Michael, and Martin Ravallion, "Short-Lived Shocks with LongLived impacts? Household Income Dynamics in a Transition Economy," PRE Working Paper No. 2459, the World Bank (October 2000).

Lustig, Nora, "Crises and the Poor: Socially Responsible Macroeconomics," Working paper No. POV-108, Inter-American Development Bank (February 2000).

Macklem, T., "Asymmetry in the Monetary Transmission Mechanism: What can we Learn from VARs?," unpublished, Bank of Canada (May 2000).

Morduch, Jonathan, "Income Smoothing and Consumption Smooting," Journal of Economic Perspectives, 9 (Summer 1995), 103-14.

Neri, Marcelo, and Mark Thomas, "Household Educational Responses to Labor-Market Shocks in Brazil: 1982-99," unpublished, the World Bank (May 2000).

Wodon, Quentin, Rodrigo Castro-Fernandez, Kihoon Lee, Gladys L.spezAcevedo, Corinne Siaens, Carlos Sobrado, and Jean-Philippe Tre, "Poverty in Latin America: Trends (1986-1998) and Determinants," unpublished, the World Bank (March 2001).

World Bank, Global Economic Prospects 2000, the World Bank (Washington DC: 2000). 
Figure 1

Brazil: Cyclical Components of Real GDP, Unemployment Rate, Real Minimum Wage, and Poverty Headcount Index, 1977-99 1/
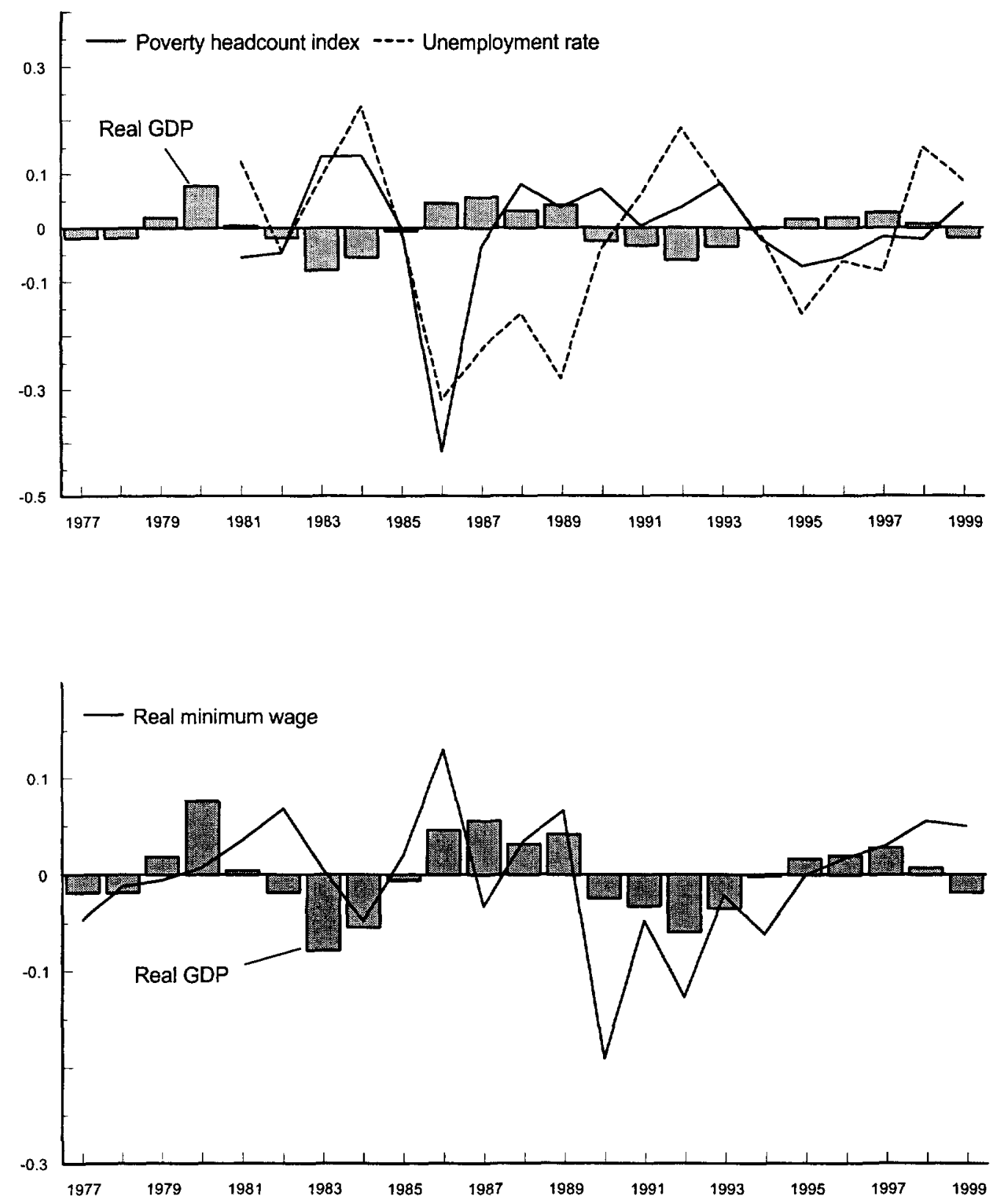

1/ The cyclical component of each variable is defined as the log difference of the variable from its trend value calculated by using the Hodrick-Prescott filtering method. 
Figure 2

Brazil: Impulse Response Function to One-Standard Deviation Innovation to Cyclical Output (Symmetric Case)

One lag
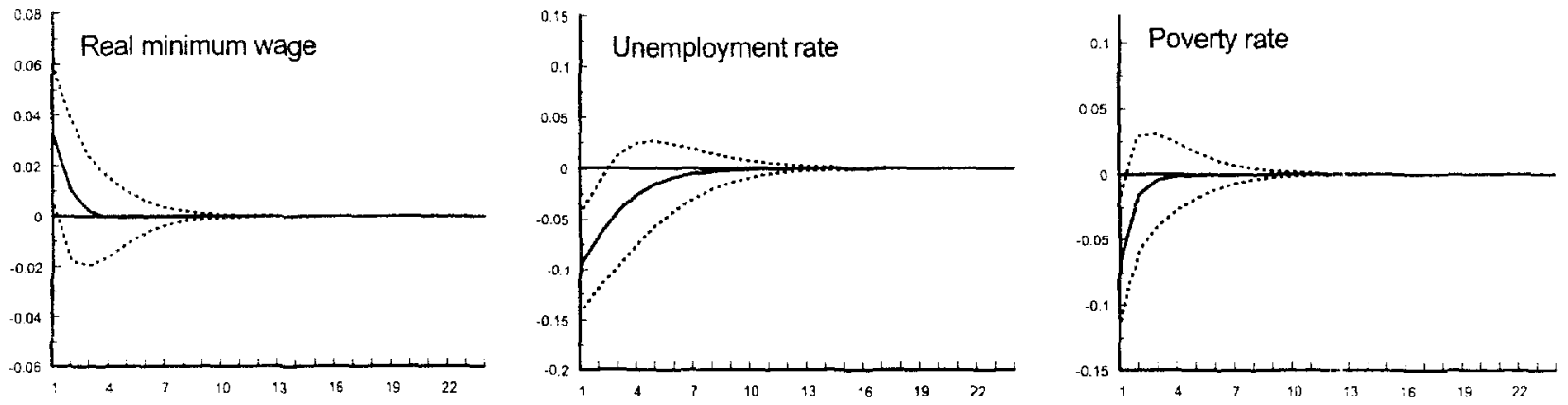

\section{Two lags}
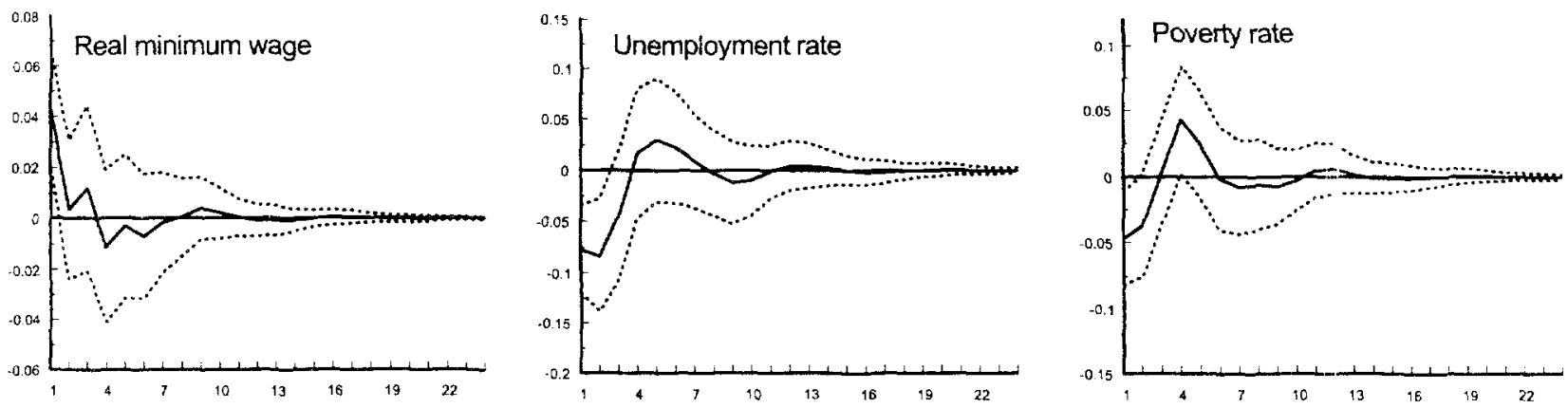

Note: Cyclical components of each variable are used. 
Figure 3

Brazil: Impulse Response Function to One-Standard Deviation Innovation to Cyclical Output (Asymmetric Case)

\section{Positive Output Gap}
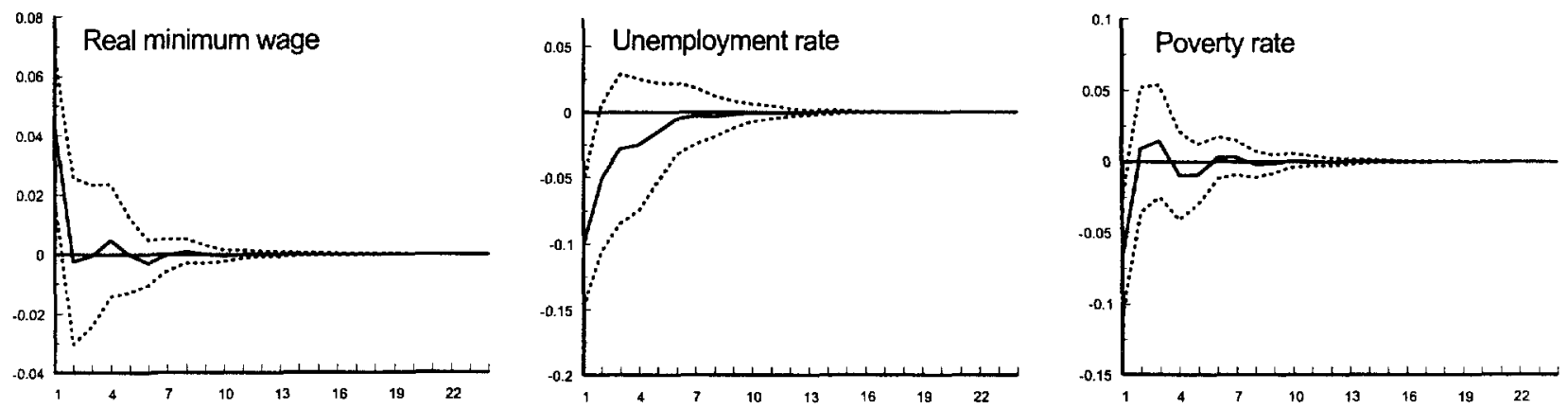

\section{Negative Output Gap}
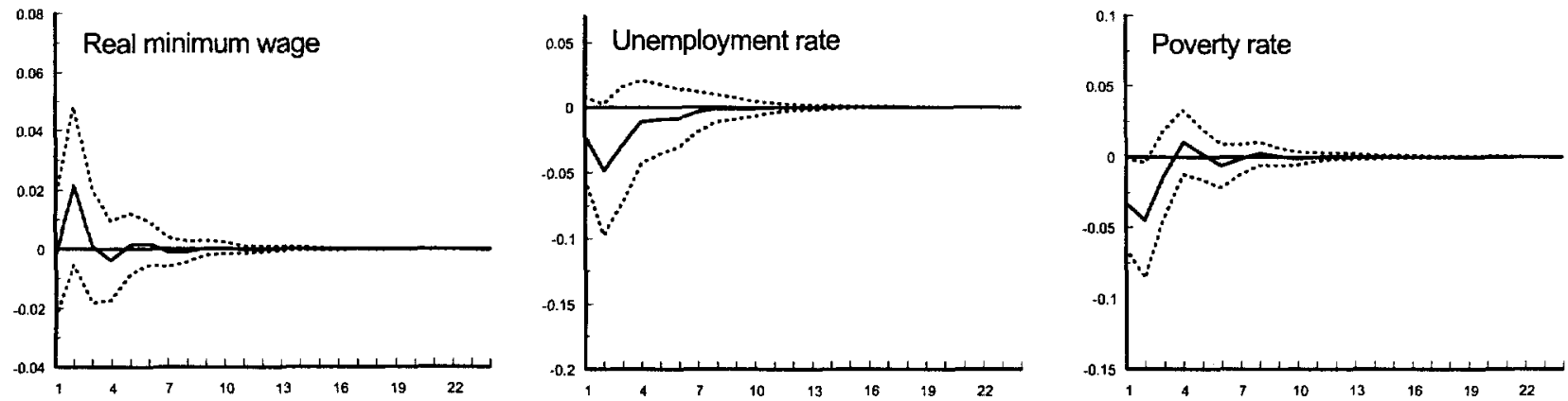

Note: Cyclical components of each variable are used. The VAR model is estimated using a uniform one-period lag. 
Figure 4

Brazil: Impulse Response Function to One-Standard Deviation Innovation to Cyclical Output (Asymmetric Case)

\section{Positive Output Gap}
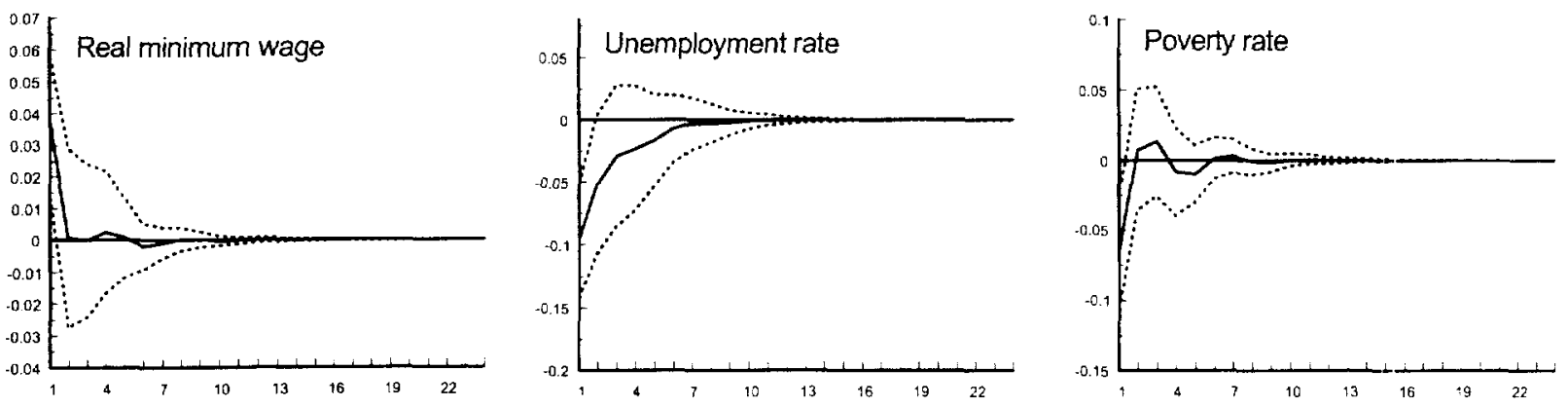

\section{Negative Large Output Gap}
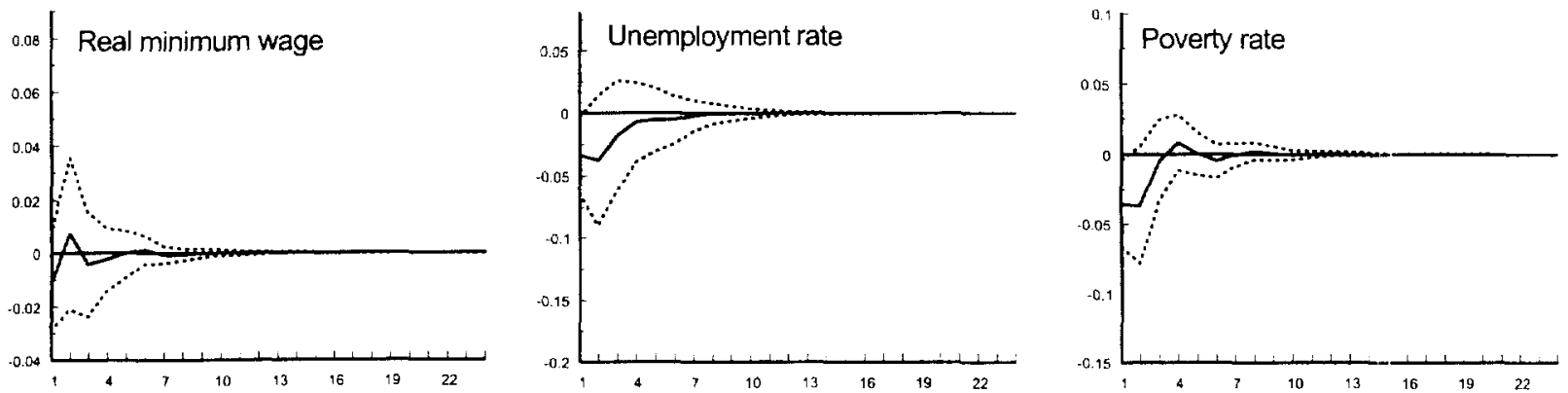

\section{Negative Small Output Gap}
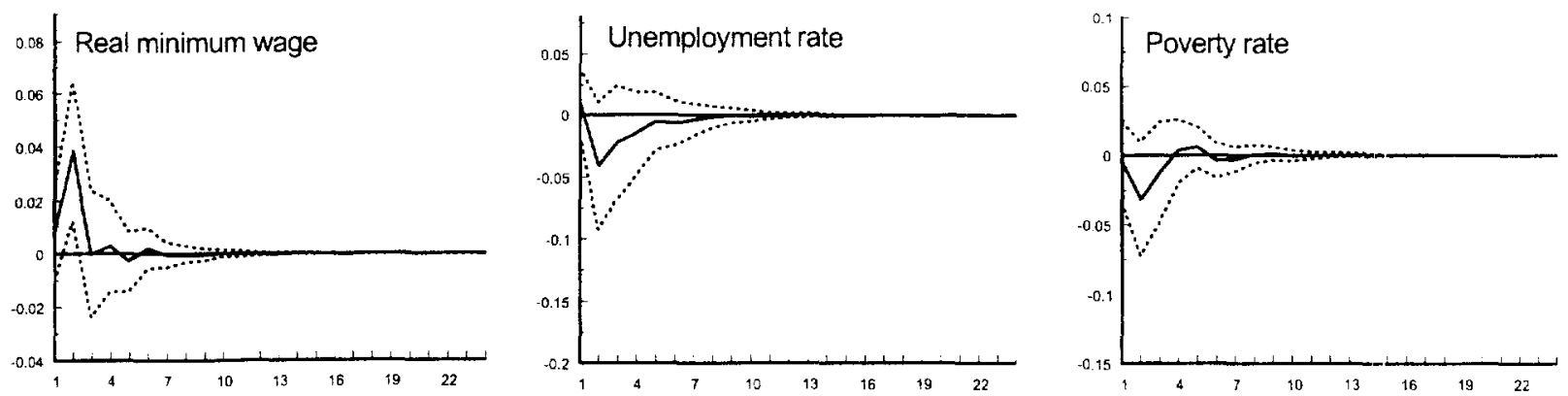

Note: Cyclical components of each variable are used. The VAR model is estimated using a uniform one-period lag. 


\section{Policy Research Working Paper Series}

\begin{tabular}{|c|c|c|c|c|}
\hline & Title & Author & Date & $\begin{array}{l}\text { Contact } \\
\text { for paper }\end{array}$ \\
\hline WPS2681 & On the Duration of Civil War & $\begin{array}{l}\text { Paul Collier } \\
\text { Anke Hoeffler } \\
\text { Måns Söderbom }\end{array}$ & September 2001 & $\begin{array}{l}\text { P. Collier } \\
88208\end{array}$ \\
\hline WPS2682 & $\begin{array}{l}\text { Deposit Insurance and Financial } \\
\text { Development }\end{array}$ & $\begin{array}{l}\text { Robert Cull } \\
\text { Lemma W. Senbet } \\
\text { Marco Sorge }\end{array}$ & September 2001 & $\begin{array}{l}\text { K. Labrie } \\
31001\end{array}$ \\
\hline WPS2683 & $\begin{array}{l}\text { Financial Policies and the Prevention } \\
\text { of Financial Crises in Emerging } \\
\text { Market Economies }\end{array}$ & Frederic S. Mishkin & October 2001 & $\begin{array}{l}\text { R. Vo } \\
33722\end{array}$ \\
\hline WPS2684 & $\begin{array}{l}\text { From Monetary Targeting to Inflation } \\
\text { Targeting: Lessons from Industrialized } \\
\text { Countries }\end{array}$ & Frederic S. Mishkin & October 2001 & $\begin{array}{l}\text { R. Vo } \\
33722\end{array}$ \\
\hline WPS2685 & $\begin{array}{l}\text { Monetary Policy Strategies for } \\
\text { Latin America }\end{array}$ & $\begin{array}{l}\text { Frederic S. Mishkin } \\
\text { Miguel A. Savastano }\end{array}$ & October 2001 & $\begin{array}{l}\text { R. Vo } \\
33722\end{array}$ \\
\hline WPS2686 & $\begin{array}{l}\text { Education, Earnings, and Inequality } \\
\text { in Brazil, 1982-98: Implications for } \\
\text { Education Policy }\end{array}$ & $\begin{array}{l}\text { Andreas Blom } \\
\text { Lauritz Holm-Nielsen } \\
\text { Dorte Verner }\end{array}$ & October 2001 & $\begin{array}{l}\text { S. Benbouzid } \\
88469\end{array}$ \\
\hline WPS2687 & $\begin{array}{l}\text { Geographic Patterns of Land Use } \\
\text { and Land Intensity in the Brazilian } \\
\text { Amazon }\end{array}$ & $\begin{array}{l}\text { Kenneth M. Chomitz } \\
\text { Timothy S. Thomas }\end{array}$ & October 2001 & $\begin{array}{l}\text { S. Hendrickson } \\
37118\end{array}$ \\
\hline WPS2688 & Aid, Shocks, and Growth & $\begin{array}{l}\text { Paul Collier } \\
\text { Jan Dehn }\end{array}$ & October 2001 & $\begin{array}{l}\text { A. Kitson-Walters } \\
33712\end{array}$ \\
\hline WPS2689 & $\begin{array}{l}\text { Global Trade and Food Safety: } \\
\text { Winners and Losers in a Fragmented } \\
\text { System }\end{array}$ & $\begin{array}{l}\text { John S. Wilson } \\
\text { Tsunehiro Otsuki }\end{array}$ & October 2001 & $\begin{array}{l}\text { L. Tabada } \\
36896\end{array}$ \\
\hline WPS2690 & $\begin{array}{l}\text { Ringing in the } 20^{\text {th }} \text { Century: } \\
\text { The Effects of State Monopolies, } \\
\text { Private Ownership,and Operating } \\
\text { Licenses on Telecommunications } \\
\text { in Europe, } 1892-1914\end{array}$ & Scot Wallsten & October 2001 & $\begin{array}{l}\text { P. Sintim-Aboagye } \\
37644\end{array}$ \\
\hline WPS2691 & $\begin{array}{l}\text { Evolution of Earnings and Rates of } \\
\text { Returns to Education in Mexico }\end{array}$ & Gladys López-Acevedo & October 2001 & $\begin{array}{l}\text { M. Geller } \\
85155\end{array}$ \\
\hline WPS2692 & $\begin{array}{l}\text { Introduction to Property Theory: } \\
\text { The Fundamental Theorems }\end{array}$ & David Ellerman & October 2001 & $\begin{array}{l}\text { B. Mekuria } \\
82756\end{array}$ \\
\hline
\end{tabular}




\section{Policy Research Working Paper Series}

\section{Title}

WPS2693 Helping People Help Themselves:
Toward a Theory of Autonomy-
Compatible Help

WPS2694 Financial Development and Financing Inessa Love Constraints: International Evidence from the Structural Investment Model

WPS2695 Trade, Credit, Financial Intermediary Development, and Industry Growth

WPS2696 Firms as Financial Intermediaries: Evidence from Trade Credit Data

WPS2697 Regional Integration and Industrial Growth among Developing Countries: The Case of Three ASEAN Members

WPS2698 Foreign Bank Entry: Experience, Implications for Developing Countries, and Agenda for Further Research

George Clarke

Raymond Fisman

Inessa Love

Asli Demirgüç-Kunt

Vojislav Maksimovic

Dorsati H. Madani

Robert Cull

Maria Soledad Martinez Peria

Susana M. Sánchez

Pierre-Richard Agénor Financial Integration: Theory and Facts

\section{Date}

October 2001

October 2001

October 2001

October 2001

October 2001
Contact for paper

B. Mekuria 82756 ;

K. Lel:orie $3100^{\circ}$

K. Labrie $3100^{*}$

K. Lalorie $3100^{-}$

L. Tahada 36896

P. Sir tim-Aboagye 38526

M. Gosiengfiao 33363 